\title{
Commercialization of Smallholder Pulse Producers in East Gojjam Zone, Ethiopia
}

\author{
Assefa Tilahun $^{1^{*}} \quad$ Jema Haji $^{1} \quad$ Lemma Zemedu $^{2} \quad$ Dawit Alemu $^{3}$ \\ 1.School of Agricultural Economics and Agribusiness Management, HARAMAYA UNIVERSITY \\ 2.Ethiopian Institute of Agricultural Research, Debrezeit Center, Ethiopia \\ 3.Bilateral Ethiopia-Netherlands Effort for Food, Income and Trade (BENEFIT) Program, Ethiopia
}

\begin{abstract}
This study examines pulse producers' commercialization using a cross-sectional data obtained from 385 randomly and proportionately selected sampled households from East Gojjam zone, Amhara National Regional State of Ethiopia. Data were analyzed using descriptive statistics and econometric model to characterize sample households and identify factors affecting pulse output commercialization. The mean commercial index for the sample households was 0.345 which indicates that on average a household sold $34.5 \%$ of his/her total pulse produce. As a result, farm households' output commercialization levels fall in semi-commercial farming system. Two limit Tobit model result indicated that farm households' crop output commercialization was positively and significantly influenced by access to improved seed, cooperative membership, land size, access to market information and pulse yield and was negatively and significantly influenced by family size and livestock owned. Based on the findings, improved seed/new varieties should be released and accessed to smallholder farmers, deliver market information timely, land owned allocation should be intensified so that smallholder producers can increase their crop output commercialization, strengthening the existing farmers' cooperatives and finally cut and carry livestock feeding system should be practiced in order to manage farm land properly.
\end{abstract}

Keywords: Pulse, commercialization, Tobit model, East Gojjam zone

DOI: $10.7176 / \mathrm{JMCR} / 58-02$

Publication date:July $31^{\text {st }} 2019$

\section{Introduction}

Agriculture is main economic pillars of the Ethiopian economy and the overall economic growth of the country is highly dependent on the success of the agriculture sector. The sector represents $38.5 \%$ of the GDP of the country and about $72.7 \%$ of the population gains their livelihood directly or indirectly from agricultural production (NPC, 2016). Moreover, Ethiopian agriculture is dominated by smallholder farming which accounts for $85 \%$ of households farming less than 2 ha and $40 \%$ less than 0.5 ha (FAO, 2014).

Agricultural commercialization brings about sustainable food security and welfare and enhances vertical and horizontal market linkages (Timmer, 1997; Pingali, 1997; Birhanu and Moti, 2010). Commercialization of smallholder farmers has been viewed by the government as the major source of agricultural growth in Ethiopia. The government of Ethiopia implemented agricultural commercialization clusters with the primary goal of commercialization of smallholders' agriculture and agro-industrial development, offering a strategic entry point for private sector engagement (Pauw, 2017).

Commercialization of agriculture involves a transition from subsistence-oriented to increasingly marketoriented patterns of production and input use. It may be defined as the proportion of agricultural production that is marketed and can be measured along a continuum from zero (total subsistence-oriented production) to unity ( $100 \%$ of production is sold) (Timmer, 1997; Pingali, 1997). Smallholder commercialization occurs when a farmer participates in agricultural markets either as a seller or buyer. This can be achieved when a portion of the agricultural produce from the farmers is marketed and/or when part of the inputs are acquired from the agricultural markets (Pingali, 1997; Osmani and Hossain, 2015). Smallholder commercialization can occur in two ways; either by increasing productivity and marketed surplus of the food crops or by focusing on cash crops (Osmani and Hossain, 2015; Sharma and Wardhan, 2015).

Ethiopia is one of the top ten producers of total pulses in the world, the second largest producer of faba beans after China, the fifth largest producer of chickpeas and the second largest producer of pulses in the common market for eastern and southern African countries (COMESA region) following Sudan (USAID, 2010). In Ethiopia, pulses are the third largest export crop behind coffee and oil seed (Boere et al., 2015).

According to CSA (2018) agricultural sample survey report in the main cropping season (Meher) of 2017/2018 about 8.32 million smallholder farmers cultivated 1.60 million hectares of land $(12.61 \%$ of the total cultivated land) with pulse crops, from which about 29.80 million quintals of pulses $(9.73 \%$ of the total harvested grain crop) was harvested. Faba beans, haricot beans, chickpea and field peas take the first four largest proportions which is about 9.21, 5.20, 4.99 and 3.68 million quintals respectively. Oromia, Amhara, SNNPR, and Tigray regions are the first four leading regions in producing pulses crops in the country. The total cultivated area under pulses in Amhara, Oromia, SNNPR, and Tigray regions is $0.68(42.40 \%) ; 0.62(39.91 \%) ; 0.24(14.75 \%)$ and 
$0.037(2.3 \%)$ million hectares of land, respectively. Considering the volume of production these four regions, Oromia, Amhara, SNNPR and Tigray regions take the largest percentage proportions which are $43.7 ; 39.47 ; 13.31$ and 1.19 , respectively. Amhara and Oromia regions alone produce $83.17 \%$ of pulse crops.

Most smallholder farmers in Ethiopia still cultivate using hoe or oxen power and rely heavily on family labor and it is dominated by subsistence, low input-low output and rain-fed farming system (Bezabih, 2010, Mitku, 2014). Market imperfections and high transaction costs have hindered smallholder farmers from exploiting the welfare outcomes of commercialization (Mitku, 2014). Therefore, it is imperative to measure and identify factors determining pulse commercialization in the output markets at the study area and draw policies and strategies to boost pulse output commercialization. There are no empirical studies conducted with regard to pulse commercialization in the study area. Hence, this study analyses pulse output commercialization levels and determinants of among smallholder pulse producers in areas of East Gojjam Zones, in Amhara National Regional State.

\section{Data and Methods}

\subsection{Description of the study area}

The study was conducted in three woredas namely Sinan, Debay Tilat Gin and Enarji Eawuga in East Gojjam zone of Amhara National Regional State of Ethiopia. The area lies at $10^{\circ} 20^{\prime}$ North latitude and $37^{\circ} 43^{\prime}$ East longitudes, and at an altitude range of 500-4154 m.a.s.l. The study zone is bordered in the South by the Oromia region, on the West by West Gojjam zone, in the north by South Gondar zone, and in the east by South Wollo zone. The bend of the Abay river defines the zone's northern, eastern and southern boundaries. The zone has 18 woredas and its zonal town is Debre Markos (DPPA, 2003). The annual rainfall of the area ranges from $900-1800 \mathrm{~mm}$ and mean minimum and maximum temperature of $7.5^{\circ} \mathrm{C}$ and $25^{\circ} \mathrm{C}$, respectively. The annual rainfall of the area ranges from 900 $1800 \mathrm{~mm}$ and mean minimum and maximum temperature of $7.5^{\circ} \mathrm{C}$ and $25^{\circ} \mathrm{C}$, respectively (Dereje et al., 2012). The study area is one of the major teff (staple food) and the second pulse crop producing areas in the region. Barely, wheat, oil seeds, sorghum, maize, wheat, oats, beans and peas are the major crops produced in large quantities (CSA, 2012).

\subsection{Data source and sampling procedure}

Both primary and secondary data are used. Primary data are collected through face-to-face interviews using structured and pre-tested questionnaire whereas secondary data are obtained from various sources such as reports of bureau of agriculture at different levels, NGOs, CSA, woreda administrative office and previous research findings. Multi-stage sampling techniques were employed to select smallholder pulse producers. In the first stage, three woredas, namely Enarg Enawuga, Sinan and Debay Tilat Gin were randomly selected from the 14 pulse crops producing woredas of East Gojjam zone. In the second stage, a total of nine pulse producing kebeles were selected by using simple random sampling method from each of the three selected woredas. In the third stage, 385 farm households were randomly selected based on the probability proportional to their total sizes/numbers.

To obtain a representative sample size for cross-sectional household survey, the study employed the sample size determination formula given by Kothari (2004):

$$
N=\frac{Z^{2} p q}{e^{2}}=\frac{(1.96)^{2}(0.5)(0.5)}{(0.05)^{2}}=385
$$

Where $\mathrm{N}$ is the sample size, $\mathrm{Z}$ is the inverse of the standard cumulative distribution that corresponds to the level of confidence, $\mathrm{e}$ is the desired level of precision, $\mathrm{p}$ is the estimated proportion of an attribute that is present in the population and $q=1-p$. The value of $Z$ is found from statistical table which contains the area under the normal curve of $95 \%$ confidence level.

\subsection{Methods of data analysis}

Descriptive statistics such as such as means, percentage and standard errors are used to analyze demographic and socio-economic characteristics of smallholder pulse producers.

\subsection{Measurement of crop output commercialization}

Household commercialization index (HCI) is used to analyze the level of pulse output commercialization. Here, the commercialization of pulse production was analyzed from the output side. The concept used in this study is also supported by other studies made on commercialization of agriculture (von Braun, 1994; Chukwukere et al., 2012) that they define output commercialization of smallholder agriculture in terms of not only cash crop but also food crops sales. According to Strasberg et al. (1999) and von Braun and Kennedy (1994), commercialization index for crop production can be defined as: 


$$
H C I=\frac{\text { Grossvalue pulsesoldinyearj }}{\text { Grossvaluepulseproducednyearj }} * 100
$$

Where; HCI represents household commercialization index of pulses. The index measures the ratio of the gross value of pulse sales by the household $i$ in year $j$ to the gross value of pulse produced by the same household $i$ in the same year $\mathrm{j}$ expressed as a percentage.

A value of zero for the HCI signifies total subsistence while a HCI value approaching 100 indicates higher degrees of commercialization. The measure is intended to measure commercialization in a scale-neutral manner, independently of the household's wealth (Rios et al., 2008).

Tobit model is the most common censored regression model appropriate for analyzing dependent variables with upper or lower limits (Tobin, 1958, Liu et al., 2013; Abu, 2015). For this study, the Tobit model was preferred because the dependent variable (output commercialization index) is bound between o and 1 and it values cluster at these points. Specifically, the output commercialization index is the dependent variable and is lower censored at zero and upper censored at 1 . Thus, a two-limit Tobit model has been chosen as a more appropriate econometric model. The two-limit Tobit was originally presented by Rossett and Nelson (1975) and discussed in detail by Maddala (1992) and Long (1997). The two limit Tobit model can be specified as:

$y_{i}^{*}=\beta^{\prime} x_{i}+\varepsilon_{i}$

where $y_{i} *$ is a latent variable (unobserved for values smaller than 0 and greater than 1 ) representing subsistence or fully commercial index; $x_{i}$ is a vector of independent variables, which includes factors affecting output sold; $\beta$ is a vector of unknown parameters; and $\varepsilon_{\mathrm{i}}$ is a disturbance term assumed to be independently and normally distributed with zero mean and constant variance $\sigma^{2}$; and $i=1,2, \ldots \mathrm{n}$ (n=the number of observations).

Given the observed dependent variable-commercialization index $\left(y_{\mathrm{i}}\right)$, the two limit Tobit model can be specified as:

$$
y_{i}=\left\{\begin{array}{l}
0 \text { if } y_{i}^{*} \leq 0 \\
y^{*} \text { if } 0<y^{*}<1 \\
1 \text { if } y^{*} \geq 1
\end{array}\right.
$$

McDonald and Moffit (1980) approach was also followed to decompose marginal effects in order to assess the effect of a change in an explanatory variables on the dependant variable. Therefore, the three types considered in the analysis of the Tobit model are shown below. These are:

a) The marginal effect on the latent variable (unconditional expected value)

$$
\frac{\partial \mathrm{E}(Y / X)}{\partial x_{k}}=\beta_{k} \Phi\left(\frac{x \beta}{\sigma}\right)
$$

b) The marginal effect on the expected value of observations conditional on being uncensored

$$
\partial \mathrm{E}\left(\frac{Y / X, y>0}{\partial x_{k}}\right)=\beta_{k}+\beta_{k} \frac{\partial \lambda(c)}{\partial c}=\beta_{k}\{1-\lambda(c)[c+\lambda(c)]\}<\beta_{k}
$$

Where, $\lambda(c)$ is called the inverse mill's ratio. It captures the change in the dependent variable (conditioned on $y>0$ ) when changing $\mathrm{x}$.

c) The marginal effect on the probability that the observations are uncensored

$$
\frac{\partial \operatorname{Pr}(y>0 / x)}{\partial x_{k}}=\phi\left(\frac{x \beta}{\sigma}\right) \frac{\beta_{k}}{\sigma}
$$

Before running the Tobit model all the hypothesized explanatory variables were checked for the existence of multicollinearity problem. There are two measures that are often suggested to test the existence of multicollinearity. These are: Variance Inflation Factor (VIF) for association among the continuous explanatory variables and contingency coefficients for dummy variables. In this study, Variance Inflation Factor (VIF) and contingency coefficients were used to test multicollinearity problem for continuous and dummy variables respectively. Following Gujarat (1995), VIF is defined as:

$\operatorname{VIF}\left(X_{i}\right)=\frac{1}{1-R^{2}}$

Where: $\mathrm{X}_{\mathrm{i}}$ is the $\mathrm{i}^{\text {th }}$ quantitative explanatory variable regressed on the other quantitative explanatory variables and $\mathrm{R}^{2}$ is the coefficient of determination when the variable $\mathrm{X}_{\mathrm{i}}$ regressed on the remaining explanatory variables.

If the value of VIF exceeds 10 , it is used as an indicator for existence of strong multicollinearity among 
continuous explanatory variables Gujarat (1995). Similarly, there may also be interaction among qualitative variables, which can lead to the problem of multicollinearity. To detect this problem, Contingency Coefficients were computed for each pair off qualitative variables. The Contingency Coefficients were computed as follows:

$C C=\sqrt{\frac{X^{2}}{n+X^{2}}}$

Where, $\mathrm{CC}=$ coefficient of contingency, $\mathrm{X}^{2}=\mathrm{a}$ chi-square random variable and $\mathrm{n}=$ total sample size. Contingency coefficient value ranges between zero and one and as a rule of thumb variable with contingency coefficient below 0.75 shows weak association and a value above it indicate strong relationship of variables Gujarat (1995).

\section{Results and Discussion}

\subsection{Demographic and Socio-Economic Characteristics of Sample Households}

The number of sample respondents were 385 . The age of the sample respondents ranges from 28 to 71 years and the average age of these respondents were 50.1 years. The average family size per sample household was 5.8 which was larger than the national average household size of 4.6 persons per household (EDHS, 2012; CSA, 2014). In addition, the sampled households walked on average 50.19 minutes to arrive the nearest market center and 33.35 minutes to reach the main road (Table 1).

The livestock species found in the study area are cattle, goat, sheep, donkey, mule, horse and poultry. Livestock is kept both for generating income and traction power. To assess the livestock holding of each household, the Tropical Livestock unit (TLU) per household was calculated. As depicted from Table 1, the average livestock holding of the sample household heads was 6.5 TLU. Land is also one of the necessary factors of production for the households in the study area. The average landholding size in the sample study area was 1.04 hectares per household which was lower than the national average land holding size of 1.17 ha per household (CSA, 2014).

Regarding sex of the sample farm household heads, about $79.5 \%$ were male-headed and the remaining $20.5 \%$ were female-headed. The result indicated that about $35.6 \%$ of the respondents have got credit services for their own pulse production. Extension services usually play a major role in disseminating new and improved farming techniques. Table 2 showed that about $71 \%$ of the farmers had contact with the development agents. Moreover, $68.1 \%$ of the sampled households have accessed market information for pulse marketing from different sources. Training received on the use of improved seed, technology adoption, agronomic practices and pre and postharvest loses will enhance agricultural productivity and in turn increases market supply of the product. Thus, the result in the study area indicated that $69.9 \%$ of the respondents have got training access.

As displayed in Table 2, 67.3\% of the sampled household heads were members of farmers' cooperatives where participation at cooperatives was believed to enhance the information exchange and experience sharing among farm households on the use of improved agricultural technologies and recommended agronomic practices. In addition, $87.8 \%$ of the sampled respondents were also participated in social engagements (edir, equib).

\subsection{Measurement of Pulse Crops Commercialization}

The proportion of households' output commercialization index was expressed through sale of grass pea, chickpea, faba bean and field pea at different levels which ranges from to 0 to 1 . As indicated in Table 3, the mean commercial index for the sampled household head was 0.345 which implied that on average a household sold $34.5 \%$ of his/her total pulse crop produce. This shows that the level of crop output commercialization in the study area was very low as compared to the national average which is about 52\% (ATA, 2016). Comparison among pulse crops show that the households commercial indices of faba bean and field pea are larger than the commercial indices of grass pea and chick pea. This indicated that households majorly sold much of their faba bean and field pea output than that of grass pea and chick pea. The survey result showed that the farm households' crop output commercialization fall in semi-commercial level. As Table 3 indicates, about $36.9 \%, 47.3 \%$ and $15.8 \%$ of the sampled households were categorized under low, medium and high commercial level respectively.

\subsection{Determinants of Pulse Outputs Commercialization}

The estimates of the Tobit model have been presented in Table 5. The result of the existence of serious problem of multicollinearity among the hypothesized explanatory variables showed that the value of VIF for each of the continuous variables is found to be low (1.5) which is less than ten. Thus, there is no a multicollinearity problem among all the hypothesized continuous variables included in the model. The result of contingency coefficient (CC) is 0.24 which implies that there was no a serious problem of association among discrete explanatory variables as the contingency coefficients is less than 0.75 .

Determinants of crop output commercialization: As indicated in Table 4, farm household's pulse output commercialization was positively influenced by improved seed used, cooperative membership, landholding size, market information access and pulse yield and it was also negatively influenced by family size and total livestock number. 
Improved seed used: The result from Table 4 showed that improved seed used positively and significantly affected crop output commercialization at less than $1 \%$. Thus improved seeds used yields higher production and were perceived to be of high quality crops results in high demand and possibly higher selling price for the crop. The results from marginal effect indicated that as household heads access to improved pulse seeds, the probability to sell their produce was increase by $17.4 \%$. This study result resembles the findings of (Kumilachew, 2016).

Family size: It is measured in terms of the number of adult equivalent in a household. It influenced the level of household commercialization negatively and significantly at five percent probability level. The probable reason was that as the number of adult people increases the level of consumption of adults will increase to the extent that it will have noticeable negative impact on the available output with the consequences of limited produce available for sale due to increased consumption and diseconomies of scale (Adam and Dawit, 2015). The result from Table 4 indicated that the level of output sale decreases by $1.5 \%$ for each additional individual in the family members. This result was consistent with the hypothesized expectation and confirms the result of Benjamin et al. (2014) and Abdu et al. (2016) that households with large family sizes need to feed their family first and take the remaining small portion surplus to the market especially if the crop is consumable at home.

Cooperative membership: It influenced crop output commercialization positively at less than ten percent level of significance. The marginal effect result revealed that for households who were members of farmers' cooperatives, the likelihood to sell their output to the market increased by $7.1 \%$. The result suggests that cooperative membership contributed to the practice of crop output market participation via its advantage of obtaining better information access to credit services. This finding is consistent with that of Rehima et al. (2013) and Stephen et al. (2017).

Landholding size: It has significantly influenced the level of pulse output commercialization. Large farms enjoy economies of scale and often produce surplus and easily become market oriented compared to small farms. This means that land plays a key role in promoting market oriented production in smallholder agriculture (Martey et al., 2012). This will enable the farmer to produce more and increase the quantity to supply to the market. The marginal effect result indicated that for households who have large farm size the probability to sell their produce to the market increases by $7.6 \%$.

Access to market information: It significantly and positively influenced crop output commercialization. Market information is very important in farming because farmers will get market prices and search for potential buyers thereby facilitating decisions on the quantity to sell. Results show that for households who have access to market information, the likelihood to sell their output to the market increases by $7.1 \%$. Access to market information is an important factor in commercialization because it presents the farmers with all the options which are available for them to choose from so as to get higher returns. In addition, market information helps to increase utilization of yield enhancing farm inputs such as fertilizers and improved varieties which eventually increases commercialization levels (Ochieng et al., 2015, Chauke et al., 2016).

Quantity of pulse produced: The level of commercialization was significantly and positively influenced by it at less than1 percent significance level. Thus, an increase in household gross production quantity will result in an increase in the household output commercialization level. An increase in household gross production quantity necessitates the producer to market the excess after taking away the portion for household consumption (Ochieng et al., 2015). If farmers are specialized in the production of pulse crops, their emphasis to produce and sell output would be increased. Thus, the result indicates that as smallholder farmers produce more quantity of pulse, the likelihood to sell their output increased by $5.8 \%$.

Total livestock number: This variable significantly and negatively affected the level of commercialization at five percent significance level. The marginal effect result shows that an increase in livestock owned by one TLU, the probability to sell pulse crops decreases by $0.5 \%$. The possible explanation was that households who have large number of livestock, the larger portion of their earnings would come from the sale of livestock and their decision to produce crops for participation in output market would be low. The other possible reason could be that smallholder farmers who have large number of livestock might allocate large proportion of their land for grazing rather than growing crops. This study result was consistent with the findings of Alelign et al. (2016).

The ancillary statistic sigma is equivalent to the square root of the residual variance in OLS regression. Sigma is statistically significant means that the estimated coefficient $(0.79)$ is statistically significantly different from 0 . The validity of this test of sigma is a matter of debate among statisticians, and some programs will produce the estimate and standard error but not the test of statistical significance (McDonald, J. F. and Moffitt, R. A., 1980).

\section{Conclusion and Recommendations}

The results from the descriptive analysis revealed that only $34.5 \%$ of pulse produce was sold. A majority of $47.3 \%$ of farmers were categorized as medium level commercialized whereas $36.9 \%$ and $15.8 \%$ were low and high commercialized farmers respectively. Besides, the average commercial index of each specific crop in the study area was estimated. The result indicated that the average commercialization index of grass pea, chickpea, faba bean and field pea were $0.25,0.28,0.42$ and 0.41 of the total production, respectively. This result may indicate 
that faba bean and field pea in the study area could contribute to household commercialization.

The econometric result showed that farm household's crop output commercialization was positively influenced by improved seed used, cooperative membership, landholding size, market information access and pulse yield and was also negatively influenced by family size and total livestock number. From this study, the following policy implications might be forwarded

Access to improved inputs is a key step in bridging the yield gap between current and potential production. Government interventions for promotion of pulses production in the country include assistances for a strong support for critical inputs, like seed, nutrients and plant protection chemicals. The use of these improved seeds still remains very low and has not been widely practiced by smallholder farmers. Thus, efforts should be targeted at encouraging smallholder farmers to grow varieties that meet international quality standards which will require appropriate cultivation and post harvest handling practices to ensure the production and delivery of quality products. Hence, it is important to provide modern inputs at the right time and the required amount at reasonable price to increase production.

Households with high family size were also not able to sell more of their pulse products in the market since the consumption will take most of it. So policy makers may need to strengthen the family planning program which is being given in the area; so that the families will have planned family size and might be produce more surpluses for market.

The results of the study indicated that market information has a significant effect to the amount supplied. Hence, market information services have to be established or strengthened to provide farmers and traders consistently and timely. Therefore, the governments and NGOs should develop and facilitate market information systems in which it is symmetrically addressable to all stakeholders.

Membership to farmer cooperatives has a significant positive influence on the pulse commercialization of smallholder producers in the study area. A farmer who is member of farmer cooperative is more likely to adopt improved agricultural technologies and hence efficient in pulse production so as to supply the produce more than others who were not cooperative members. Thus it is important to strengthen the existing farmer cooperatives to reinforce farmer-to-farmer knowledge sharing through providing awareness creation, incentives and providing various facilities by the regional and local government.

Size of land allocated to pulse production positively and significantly affected the level of pulse commercialization. However, increasing the size of landholding was impossible since land is a limited resource. Interventions are needed to increase productivity of pulse per unit area of land through delivering appropriate and improved pulse production technology that increase smallholder farmers' commercialization. Hence, proper utilization of land resource requires intensifying the farm practices through provision of sustainable and timely supply of inputs, increasing the farmers' awareness creation on improving soil fertility and application of improved inputs which helps the farmer to produce and supply more pulse crops to the market.

\section{Acknowledgements}

The authors would like to thank Ministry of Education for financial support for this research. Moreover, we warmly thank the sample respondents, enumerators and districts experts for their valuable response during data collection process.

\section{References}

Abu, B. (2015). Groundnut Market Participation in the Upper West Region of Ghana. Ghana Journal of Development Studies, 12 (1): 106-124

Abdu Muhie, Melkamu Baze \& Mohammed Ahmed. (2016). Smallholder Commercialization and Commercial Farming in Coffee-Spice Based Farming System of South West Ethiopia. International Journal of Research Studies in Agricultural Sciences, 2 (5): 13-26

Adam Bekele \& Dawit Alemu. (2009). Farm-Level Determinants of Output Commercialization: In Haricot Bean Based Farming Systems

Alelign Ademe. (2018). Crop Productivity, Efficiency and Commercialization of Smallholder Farmers in the Highlands of Eastern Ethiopia. PhD Dissertation, Haramaya University, Haramaya

ATA (Agricultural Transformation Agency). (2016). Agricultural Transformation Agenda. Annual Report of 2015-16 Production Season, Addis Ababa, Ethiopia

Benjamin, A., Yaw B., O., \& Seini, W. (2014). Market Participation of Smallholder Maize Producers in the Upper West Region of Ghana. African Journal of Agricultural Research, 9 (31): 2427-2435

Bezabih Emana . (2010). Market Assessment and Value Chain Analysis in Benishangul Gumuz Regional State, Ethiopia. Sid-Consult-Support Integrated Development, Addis Ababa, Ethiopia

Boere, A., Rutgers,T., Willems, D.\& Dolfen, W. (2015). Business Opportunities Report Oilseeds and Pulses in the Series Written for the Ethiopian Netherlands Business Event 5-6 November 2015, Rijswijk, The Netherlands

Chauke, P.K., Kabiti, H.M. Raidimi, N.E. \& Pfumayaramba, T.K. (2016). Determinants of Agricultural 
Commercialization among Smallholder Farmers in Munyati Resettlement Area, Chikomba District, Zimbabwe

Chukwukere, A. O., J. Sulaiman1, A. C., \& Nwosu. (2012). Farm Level Determinants of Agricultural Commercialization. International Journal of Agriculture And Forestry. 2(2): 1-5

CSA (Central Statistical Agency). (2012). The Federal Democratic Republic of Ethiopia Central Statistical Agency Key Finding of Agricultural Sample Surveys. Addis Ababa, Ethiopia

CSA (Central Statistical Agency). (2014). Agricultural Sample Survey 2013/2014. Report on Area, Production and Farm Management Practice of Belg Season Crops for Private Peasant Holdings. Statistical Bulletin Number 532. Central Statistical Agency, Addis Ababa, Ethiopia

CSA (Central Statistical Agency). (2018). The Federal Democratic Republic of Ethiopia Central Statistical Agency Agricultural Sample Survey Report on Area and Production of Major Crops Statistical Bulletin 2016/2017

Dereje Ayalew, Kindie Tesfaye, Girma Mamo, Birru Yitaferu \& Wondimu Bayu. (2012). Variability of Rainfall and Its Current Trend in Amhara Region, Ethiopia. African Journal Of Agricultural Resource. 2012; 7 (10): $1475-86$

DPPA (Disaster Prevention and Preparedness Agency). (2003). Amhara National Regional State Resettlement Reports, Addis Ababa, Ethiopia

EDHS (Ethiopia Demographic and Health Survey). (2012). Ethiopia Demographic and Health Survey report 2011, Addis Ababa, Ethiopia

FAO. (2014). Food and Agriculture Organization Ethiopia country programming framework. Office of the FAO Representative in Ethiopia to AU and ECA Addis Ababa, 2014

Gabrielle, K. (2016). Pulse Crops and Sustainability: A Framework to Evaluate Multiple Pulse Benefits. HTTP://WWW.FAO.ORG/Pulses-2016

Gujarati, D.N. (1995). Basic Econometrics. $3^{\text {rd }}$ Edn., McGraw-Hill Inc., New York, USA., ISBN-13: 9780070252141, Pp: 838

Kumilachew Alamerie. (2016). Commercial Behaviour of Smallholder Potato Producers: The Case of Kombolcha Woreda, Eastern Part of Ethiopia. UDC 633.49:631.1.017.3:330.13(63)

Kothari, C. R. (2004). Research Methodology: Methods and Techniques, $2^{\text {nd }}$ Edition. New Age International, New Delhi, India

Liu, X.,Wang Z., \& Wu, Y. (2013). Group Variable Selection and Estimation in the Tobit Censored Response Model. Computational Statistics And Data Analysis, 60: 80-89

Maddala, G.S. (1992): Introduction to Econometrics Second Edition. Macmillan Publishing Company, New York

Martey, E., Al-Hassan, R. \& Kuwornu, J. (2012). Commercialization of Smallholder Agriculture in Ghana A Tobit Regression Analysis. African Journal of Agricultural Research, 7(14): 2131-2141

McDonald, J.\& Moffitt, R. (1980). The Uses of Tobit Analysis. Review of Economics and Statistics, 62, 318-321

Mitku, A. (2014): Impact of Smallholder Farmers' Agricultural Commercialization on Rural Households' Poverty. International Journal of Applied Economics and Finance Vol. 8, No. 2, Pp. 51-61

Moti Jaleta, Birhanu Genremedhin \& Hoekstra, D. (2011). Smallholder Commercialization: Processes, Determinants and Impact. Discussion Paper No. 18. Improving Productivity and Market Success (IPMS) of Ethiopian Farmers Project, ILRI (International Livestock Research Institute), Nairobi, Kenya. 55 Pp

NPC (National Plan Commission). (2016). Growth and Transformation Plan II (GTP II), National Plan Commission Volume I: Main text Addis Ababa, Ethiopia

Ochieng, J., Beatrice, K., George, O. \& Emily, O. (2015). Agricultural Commercialization and Household Food Security: The Case of Smallholders in Great Lakes Region of Central Africa

Osmani, AG., \& Hossain, E. (2015). Market Participation Decision of Smallholder Farmers and Its Determinants in Bangladesh. Journal of Economics of Agriculture, 62(1): 163-179

Pauw, S. (2017). Agricultural Commercialization in Ethiopia: A Review of Warehouse Receipts in the Maize, Wheat, Sorghum and Teff Value Chains. USAID/Ethiopia Agriculture Knowledge, Learning, Documentation and Policy Project, Addis Ababa, Ethiopia

Pingali, P. (1997). From Subsistence to Commercial Production System: The Transformation of Asian Agriculture. American Journal of Agricultural Economics 79 (2):628-634

Rehima Mussema, Belay Kassa, Dawit Alemu \& Rashid, S. 2013. Factors Affecting Farmers' Crops Diversification: Evidence from SNNPR, Ethiopia. International Journal of Agricultural Sciences, 3(6): 558565

Rios, A. R., Masters, W. A. \& Shively, G. E. (2008). Linkages between Market Participation and Productivity: Results From a Multi-Country Farm Household Sample [Conference Paper]. American Agricultural Economics Association Annual Meeting. Orlando, FL.

Rosett, R., And Nelson, F. 1975: Estimation of the Two-Limit Probit Regression Model. Econometrica, 43, Pp. 141-146

Sharma, PV \& Wardhan, H. (2015). Assessment of Marketed and Marketable Surplus of Major Food Grains in 
India. Centre for Management in Agriculture (CMA) Indian Institute of Management

Stephen, K., Mshenga, P. \& Eliud, B. (2017). Factors Influencing Commercialization of Beans among Smallholder Farmers in Rwanda

Strasberg, P.J., Jayne, T.S., Yamano, T., Nyoro, J., Karanja, D. \& Strauss, J. (1999): Effects of Agricultural Commercialization on Food Crop Input Use and Productivity in Kenya. Office of Sustainable Development; Policy Synthesis for USAID-Africa Bureau, Pp. 41

Timmer, C.P. (1997). Farmers and Markets: The Political Economy of New Paradigms. American Journal of Agricultural Economics 79 (2): 621-627

Tobin, J. (1958). "Estimation of Relationships for Limited Dependent Variables". Econometrica, 31: 24-36

Usaid. (2010). Staple Food Value Chain Analysis. Ethiopia, Volume 2 Issue 2 - 2015

von Braun, J. \& Kennedy, E.(1994). Agricultural Commercialization, Economic Development and Nutrition. The Johns Hopkins University Press, Baltimore and London

Table 1: Summary statistics of the sample households (continuous variables)

\begin{tabular}{|l|c|c|c|c|}
\hline Variables & Min & Max & Mean & Std.Err \\
\hline Age of household head (years) & 28 & 71 & 50.07 & 0.56 \\
\hline Educational level (years of schooling) & 0 & 8 & 1.21 & 0.10 \\
\hline Farming experience of household head (years) & 8 & 49 & 29.2 & 0.54 \\
\hline Family size in adult equivalent & 3 & 9 & 5.8 & 0.06 \\
\hline Distance to main market(min) & 25 & 80 & 50.2 & 0.58 \\
\hline Distance to main road(min) & 15 & 45 & 33.4 & 0.33 \\
\hline Distance to development agents (min) & 10 & 45 & 30.1 & 0.35 \\
\hline Landholding size(ha) & 0.50 & 1.75 & 1.16 & 0.02 \\
\hline Land allocated for pulse crops (ha) & 0.06 & 0.63 & 0.33 & 0.01 \\
\hline Total number of livestock (TLU) & 1 & 14 & 6.64 & 0.113 \\
\hline
\end{tabular}

Source: Computed from survey data (2019)

Table 2: Summary statistics of sample households (categorical variables)

\begin{tabular}{|l|c|c|c|}
\hline Variable & Description & No. of respondents(n=385) & Percent \\
\hline \multirow{2}{*}{ Sex of household head } & Male & 307 & 79.7 \\
\cline { 2 - 4 } & Female & 78 & 20.3 \\
\hline Credit Access & Yes & 137 & 35.6 \\
\hline Extension participation & Yes & 273 & 70.9 \\
\hline Coops membership & Yes & 259 & 67.3 \\
\hline Social participation & Yes & 338 & 87.8 \\
\hline Training Access & Yes & 269 & 69.9 \\
\hline Market information & Yes & 262 & 18.1 \\
\hline Off-farm participation & Yes & 70 & 70.9 \\
\hline Access to improved seed & Yes & 273 & 67.8 \\
\hline Access to chemical fertilizer & Yes & 261 & 61.9 \\
\hline Access to field chemical & Yes & 238 & \\
\hline
\end{tabular}

Source: Computed from survey data (2019)

Table 3: Commercial indices of crops and commercialization status of households

\begin{tabular}{|l|c|c|c|c|}
\hline \multicolumn{1}{|c|}{ Description } & Min & Max & Mean & Std. Err. \\
\hline Commercial index of grass pea & 0.00 & 1.00 & 0.252 & 0.016 \\
\hline Commercial index of chickpea & 0.00 & 1.00 & 0.288 & 0.016 \\
\hline Commercial index of faba bean & 0.00 & 1.00 & 0.428 & 0.016 \\
\hline Commercial index of faba bean & 0.00 & 1.00 & 0.413 & 0.015 \\
\hline Aggregated commercial index & 0.00 & 0.81 & 0.345 & 0.013 \\
\hline \multicolumn{6}{|c|}{ Percent } \\
\hline Number & 42 & 36.9 \\
\hline Commercial status & Midium & 182 & 47.3 \\
\hline
\end{tabular}

Note: Aggregated crops represent four crops (grass pea, chickpea, faba bean and field pea) Source Author's computation from sample survey data (2019) 
Table 4: Parameter estimates of two-limit Tobit model for commercialization index

\begin{tabular}{|l|c|c|c|}
\hline Variables & Coef. & Std.Err. & Marginal effect \\
\hline Sex of household head & $0.049^{*}$ & 0.024 & 0.049 \\
\hline Age of household head & 0.001 & 0.001 & 0.001 \\
\hline Education status & 0.008 & 0.005 & 0.008 \\
\hline Family size & $-0.015^{* *}$ & 0.005 & -0.015 \\
\hline Distance to market & -0.000 & 0.001 & -0.001 \\
\hline Distance to road & -0.001 & 0.001 & -0.001 \\
\hline Landholding size & $0.076^{*}$ & 0.048 & 0.076 \\
\hline Access to improved seed & $0.174^{* * *}$ & 0.036 & 0.174 \\
\hline Chemical fertilizer use & 0.006 & 0.024 & 0.006 \\
\hline Training access & 0.027 & 0.037 & 0.027 \\
\hline Field chemical use & 0.034 & 0.018 & 0.034 \\
\hline Cooperative membership & $0.071^{*}$ & 0.038 & 0.071 \\
\hline Access to market information & $0.075^{* *}$ & 0.041 & 0.075 \\
\hline Off-farm participation & -0.008 & 0.028 & -0.008 \\
\hline Tropical livestock unit(TLU) & $-0.005^{* *}$ & 0.003 & -0.005 \\
\hline Quantity of pulse yield & $0.058^{* * *}$ & 0.006 & 0.049 \\
\hline Constatnt & $1.89^{*}$ & & \\
\hline Sigma & 0.791 & & \\
\hline
\end{tabular}

$\operatorname{LR~chi}^{2}(16)=850.56$

Prob $>\mathrm{chi}^{2}=0.000$

Log likelihood $=225.69$

Number of observation $=385$

Note: $* * *, * *$ and $*$ indicate significance at $1 \%, 5 \%$ and $10 \%$ levels, respectively.

Source: Model output based on survey data, 2019

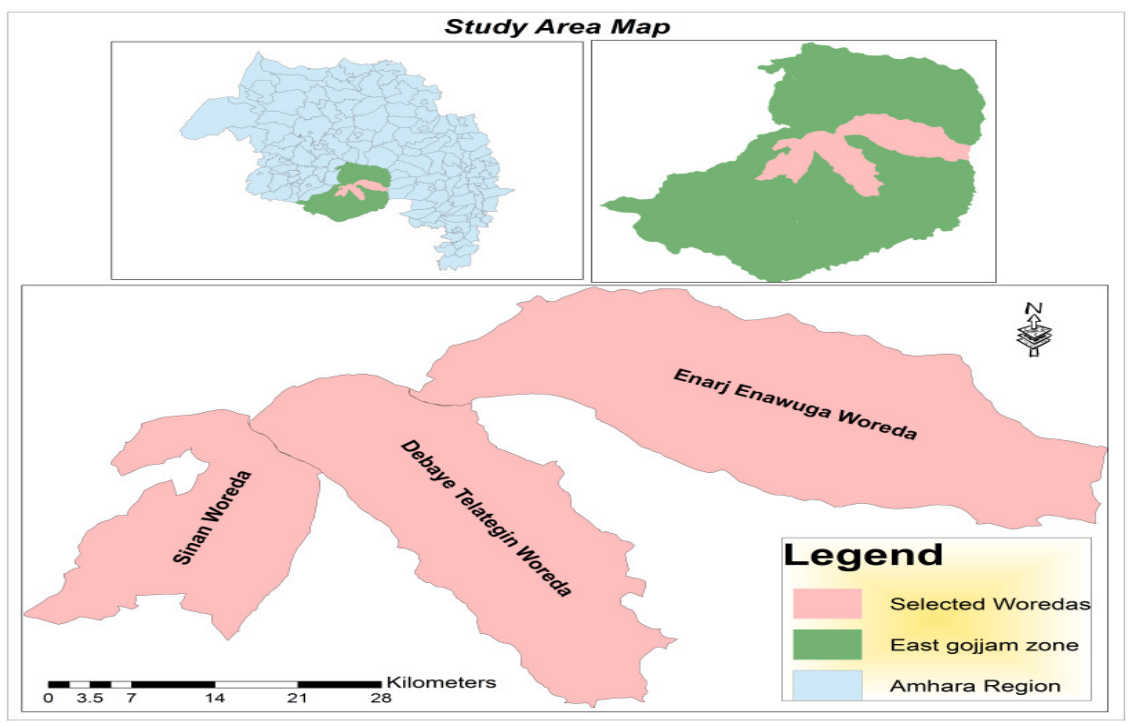

Figure 1. Map of the study are 